\title{
UNDERSTANDING OF TEACHERS AND HEALTHCARE PROFESSIONALS ABOUT THEIR PROFESSIONAL DEVELOPMENT
}

\author{
Oskars Kaulēns, Reinis Upenieks \\ University of Latvia, Latvia
}

\begin{abstract}
Changes in technology use and globalization are leading to significant changes in the structure of the labor market, emphasizing the need for labor market participants to learn continuously and acquire new knowledge and skills in order to adapt to a rapidly changing work environment. Economists point to the risks posed by technological development, such as the reduction of low-skilled jobs as a result of digitalization and automation processes. Although professionals working with people, such as healthcare professionals and teachers, are less exposed to the risk of automation, they are still increasingly unstable as technology and artificial intelligence compete with human experts. This means that medical and education staff will also need more targeted, regular and labor market-oriented professional development in order to remain competitive and demonstrate demand-driven performance. In line with changes in the quality standards of professional performance for healthcare professionals and teachers, changes are also taking place in how the professional development of these groups is implemented. In addition to formal development activities such as courses and seminars, the need to accept the impact of informal learning is emphasized, not only expanding the aims and content of professional development activities but also offering new learning formats.

The aim of the qualitative research conducted by the authors is to study the understanding of teachers and healthcare professionals about their professional development by analyzing their answers regarding their professional development. The focus of the study has been chosen to test the assumption that healthcare professionals and teachers view their continuing education more in the context of formal training, with less emphasis on professional development through informal learning. Within the framework of the research, a survey of random respondents within the said target groups has been conducted and the answers of the respondents have been analyzed, with attention paid to the aspects of formal and informal learning. The article presents the results of the content analysis, highlighting the most important trends of study results and the problematic aspects related to the improvement of the quality of professional development.
\end{abstract}

Keywords: attitudinal development, formal learning, functional development, healthcare professionals, informal learning, professional development, teachers. 


\section{Introduction}

Changes in patterns of technology use and globalization are also leading to significant changes in the structure of the labor market, emphasizing the need for all labor market participants to learn continuously and acquire new knowledge and skills in order to adapt to a rapidly changing work environment. The Organization for European Co-operation and Development (OECD) points to the need for countries and organizations to develop sustainable adult education programs, providing employees with the opportunity to retrain and strengthen their competencies in their professional field (OECD, 2019).

Economists point to the risks to employment posed by the rapid development of technologies, such as the reduction in the number of low-skilled jobs due to digitalization and automation processes (World Bank, 2013). It is predicted that workplace automation will have less of an effect on those areas where employees need a high level of education, the ability to manage themselves and others, and the ability to plan and coordinate complex processes (Ministry of Economics of the Republic of Latvia, 2020).

On the one hand, this leads to the conclusion that professionals such as healthcare professionals and teachers, whose work specifics are directly related to working with people, are less exposed to the risk of automation. On the other hand, these professions also become more unstable as technology and artificial intelligence compete with human expertise (Susskind \& Susskind, 2015). This means that medical and education staff will also need more targeted, regular and labor market-oriented professional development in order to remain competitive and demonstrate demand-driven performance.

In line with changes in the quality standards of professional performance of healthcare professionals and teachers, changes are taking place in the way in which the professional development of these groups is implemented. In addition to formal development activities such as courses, conferences and seminars, the need to accept the impact of informal learning and incidental learning is emphasized (Marsick \& Watkins, 1990, 2020; Eraut, 2004), thus extending not only the aims and content of professional development but also offering new learning formats.

The aim of the research conducted by the authors is to study the understanding of healthcare professionals and teachers about their professional development by analyzing their answers about what professional development is and in what ways the representatives of these professional groups supplement their knowledge and skills. This focus of the study has been chosen to test the assumption that healthcare professionals and teachers view their continuing education more in the context of formal learning, 
with less emphasis on professional development that takes place through informal and incidental learning.

\section{Previous findings}

Although there is a link between an individual's professional development and professionalism, society's understanding of what it means to be a professional in one's field has changed over time. Professionalism is related to the job responsibilities and functions that a representative of a particular field has to perform according to his or her job description, with certain skills and knowledge necessary for the successful performance of one's duties (Evans, 2008, 2015). Professionalism determines what performance and expertise are expected of the professionals, while defining their future learning needs to demonstrate such performance. In a case of teachers and healthcare workers, professionalism is the way what they think about their profession and how they behave and implement their professional knowledge and skills related to the profession (Wardoyo, Herdiani \& Sulikah, 2017).

Professionality is not a constant description of the ideal performance expected of every employee in the field. It is more of a socially constructed and contextual variable; it relates to the requirements imposed on employees to perform certain duties (Troman, 1996). This means that as society changes, the criteria by which the practical performance of professionals is assessed also change, and new improvement and learning outcomes are defined (Kumar \& Ganguly, 2021) to meet the collective demands of organization and society.

In the case of teachers' professional development can be defined as different activities that enables improvement in teachers' knowledge and teaching practices with the goal to better student learning (DarlingHammond et al., 2017). Another view of professional development is defined as the growth of the employee beyond the formal education qualification and standardized learning experience (Stevenson, 2010). This means that professional development is linked to the choices and purposes which employees make for their further learning after obtaining professional qualifications and starting their careers.

The goal of professional development is to improve the employee's performance in working with clients, to implement the necessary changes in employees' attitudes and beliefs, as well as to improve client achievements (Guskey, 2002). In the context of the professional development of teachers and healthcare professionals, this means acting as effectively as possible to meet the needs of their clients - students and patients. Professional development goals and learning needs also differs according to the previous work experience of professionals and stages of their professional life (Louws et al., 2017). 
Within the framework of the professional development of employees, it is important to emphasize both functional improvement, which is related to employees' practical work with clients, and attitudinal development, which changes employees' motivation and view of responsibilities and their role in meeting clients' needs. The professional development of attitudes includes the intellectual and motivational growth of employees, while functional development focuses more on procedural improvement (Evans, 2008). It means that professional development is a "combination of intellectual, attitudinal and functional development which provides teachers with knowledge, skills and professional understanding supporting teaching for the benefit of student achievement, school professionalization and accompanying the implementation of educational reforms" (Zeggelaar, Vermeulen \& Jochems, 2017).

In order to improve professional performance, there are various aspects to the development of employees: knowledge of content, which allows them to improve the performance of their duties at work; knowledge of the process, which helps them to understand how specific tasks are performed; day-to-day knowledge, which helps them to orientate themselves in the environment where responsibilities are performed; attitudes, values and beliefs; unconscious knowledge, which allows them to perform duties without additional thinking; and professional skills, which provide opportunities for them to perform the assigned duties more effectively (Jarvis, 2004).

Professional development is a way for employees to learn new methods and techniques and help them to prepare for the changes that take place in a society where the work environment and conditions change and new customer needs are defined (Jones \& Dexter, 2014). As a part of professional development, employees' skills are improved, a new understanding of professional goals and results is achieved, problem-solving skills are improved, the ability to work with colleagues is improved, and other changes in employees' practice take place (Hargreaves \& Fullan, 2012). Professional development is the process by which an individual acquires new or improves existing skills, knowledge and attitudes in order to improve their professional practice (Mitchell, 2013).

In the context of professional development, there are several ways in which it can happen in accordance with changes taking place in society, organizational development goals and personal development goals for employees. Thus, for example, professional development can take place within the framework of formal education, where the development of new knowledge and skills takes place in accordance with previously defined rules and learning outcomes to be achieved; within non-formal education, where specific groups of people acquire specific knowledge and skills outside the framework of formal education; or within informal education, where 
learning is not purposefully organized and managed and the acquisition of new knowledge and skills takes place unconsciously (Melnic \& Botez, 2014).

Formal professional development usually takes place in in-service training courses, seminars, lectures, workshops, etc. in formats that are structured, externally driven and provide pre-defined learning outcomes. Formal professional development is focused on single events, such as lectures and workshops led by external experts in the concrete field to promote mastery of certain professional skills and competences (Bergmark, 2020). However, the impact of such learning experiences on employee achievement is questionable, as employees rarely use methods that have been learned in formal learning without purposeful reflection on the content learned and how it is linked to their performance in daily practice (Wideen et al., 1998).

The knowledge and skills acquired during formal learning are rapidly becoming obsolete and no longer meet the professional standard, which is why new ways to update them continuously need to be explored (van Veelen et al., 2017). In addition, part of the professional learning in organizations takes place accidentally and unconsciously (Eraut, 1994), rather than in a formalized learning process.

Informal learning is the acquisition of new knowledge and skills outside a structured, institutionally organized learning environments and contexts (Cerasoli et al., 2018). It takes place in a voluntary collaborative process, where employees of the organization share experiences and engage in negotiations without clearly defined learning goals (Marsick et al., 2008). Some authors describe informal learning as indirect and unplanned learning that does not highlight the person who teaches others (Eraut, 2004) because learning takes place in the process of social interaction. The aim of informal learning is not to acquire specific, pre-defined content but to implement the exchange of experiences and ideas between employees and to improve their instructional skills and knowledge (Louws et al., 2017; Jeong et al., 2018).

Informal learning takes place both within individual activities, such as reading and analyzing professional literature, establishing social contacts with other professionals in one's own or another field and observing the performance of other professionals, and within collective activities such as mentoring or involvement in professional networks (Desimone, 2009). Informal learning provides greater flexibility and freedom for participants as opposed to a formal learning process, emphasizes the need and offers the opportunity to learn from other professionals, and takes place in various forms and allows the employee to update and use the professional experience accumulated within the organization (Sjöberg \& Holmgren, 2021).

However, informal learning, which takes place inside or outside of an organization, can be planned and formalized to ensure better learning 
outcomes, for example by pre-determining which professional development activities employees need to engage in. This means that the structure of professional development can be formalized, but the learning process itself remains informal. Thus, different types of professional development in the workplace can be distinguished: casual informal learning, planned informal learning, and formal learning (Billet, 2004, 2011). Another type of professional development - incidental learning - is introduced by Marsick \& Watkins (1990, 2020). Unlike informal learning, incidental learning always takes place unplanned and is often a side effect of other activities in the workplace.

In sum, formal learning takes place through purposefully organized courses and seminars, where employees are taught specific, pre-defined skills and knowledge. In turn, informal learning takes place as part of the daily work process, which provides indirect knowledge without a specific, obvious purpose of application. Therefore, the professional development of employees through informal learning is not enough, because it provides indirect, difficult-to-assess knowledge. In addition, there is no guarantee that all the necessary competencies are already available within the organization. Therefore, there is also a need for formal learning and pre-planned learning activities that create the conditions for a meaningful informal learning process and allow unconsciously acquired knowledge to be transformed into everyday practice (Slotte et al., 2004).

\section{Method and design}

The data for the research were obtained following the dissemination of the questionnaire which was prepared electronically using the Google Sheets form and distributed from December 1, 2020 using the method of Snowball Sampling. Snowball Sampling is a data collection method providing an opportunity to pass the questionnaire to potential respondents who then distribute it to other respondents (Oliver, 2011) to expand the circle of respondents in situations when the researchers do not have access to the selected target group (Given, L. M., 2012). In total, 126 responses had been received by December 16, and after a few days when no additional responses were received, the survey was closed on December 20. The participants gave their consent for their responses to be used anonymously and any references to them would not allow them to be individually identified. After 6 duplicates were deleted, a total of 120 surveys were selected for analysis (60 teachers, 60 healthcare professionals).

The emphasis of the survey was two open-ended questions about what the representatives of the selected professional groups understand by the concept of "professional development" and how they improve their 
knowledge and skills for the successful performance of their duties. Within the framework of the research, the respondents were not offered closedended questions with previously prepared answer variants in order to reduce the risk of socially desirable answers that may arise when survey participants choose from answers offered by the researchers. The survey also included seven questions relating to the participants' demographics (age, gender, geographic region, etc.) as well as their professional affiliation, amount of work experience, and so on.

The content of the answers obtained within the framework of the survey has been analyzed and classified into the relevant research categories. In the category "professional development goals" attention is paid to whether the respondents' answers show indications of the development of knowledge, skills or views within the framework of professional development. In turn, in the category "forms of professional development" it is analyzed whether the answers of the respondents indicate professional development by way of formal or informal learning. The opinions of respondents were analyzed using the principles of qualitative content analysis. It is a method that involves the systematic and objective selection of qualitative data according to defined research categories with a goal to reduce the amount of qualitative data obtained within research, so that it can be described and interpreted (Schreier, 2013). For purposes abovementioned QSR International's NVivo 12 software was used (QSR International Pty Ltd., 2020).

\section{Results}

After deleting duplicates from the survey responses, there appeared to be 60 respondents from healthcare and 60 from the field of education. Of the 120 respondents, $88 \%$ were female and $12 \%$ were male (across both in medicine and education) - according to the state census bureau, this reflects the tendency of the Latvian population to work in said professions.

Table 1. Professional experience (years)

\begin{tabular}{|l|c|c|c|c|}
\hline Group & Min & Max & Average & Standard deviation \\
\hline Teachers & $<1$ & 43 & 17.60 & 12.96 \\
\hline Healthcare professionals & 1 & 38 & 15.82 & 10.63 \\
\hline All respondents & $<1$ & 43 & 16.71 & 11.83 \\
\hline
\end{tabular}

The data obtained in the study show that there are no significant differences in how the surveyed teachers and healthcare professionals reflect on their professional development and which professional development 
activities they participate in to improve their performance. For example, references to formal professional development activities - participation in conferences, seminars, workshops, masterclasses, etc. - appear 88 times in the answers of the surveyed healthcare professionals and 78 times in the case of teachers. In turn, references to informal learning - which takes the form of involvement in informal conversations with colleagues, independent acquaintance with the latest scientific literature and research results, participation in professional cooperation networks, etc. - appear 69 times in the answers of the surveyed healthcare professionals and 89 times in the answers of teachers.

When asked what they understand by the concept of "professional development" one of the healthcare respondents (female, 47) indicated that it is about participation in international conferences in the field of his direct activity and national conferences in related fields of activity, which are necessary to provide new examples to be used in professional practice. Another healthcare respondent (female, 41), on the other hand, answered this question by saying that professional development is the "periodic attendance of courses, seminars and other educational events." These answers indicate formal professional development in terms of the ways in which the further education of teachers and healthcare professionals is implemented.

In turn, with regard to informal learning, the respondents' answers reflect a wide variety of professional development activities that are used to achieve learning outcomes. Thus, for example, one teacher respondent (female, 41) states that she implements her professional development "by meeting regularly with colleagues to share ideas, looking for opportunities for mutual cooperation, creating teaching materials for students, as well as using various sources and experience of other colleagues." Another healthcare respondent (female, 37) states that in order to implement her professional development, she communicates with representatives from other countries and reads articles in internationally cited journals in order to find out the results of the latest research and learn from them.

Such results can be explained by the fact that formal learning is still an important set of professional development activities that is determined by historical traditions and the existing regulatory framework in Latvia. According to the requirements, teachers need to participate in 36 hours of professional development activities within 3 years (Cabinet of Ministers of the Republic of Latvia, 2018), and healthcare professionals have to obtain 100 to 250 continuing education points $(1$ continuing education point $=$ 1 academic hour) within 5 years for recertification (Cabinet of Ministers of the Republic of Latvia, 2012). In turn, the proportion of responses involving informal learning can be explained by the fact that the audience of 
teachers and healthcare professionals increasingly emphasizes the need to learn from the professional expertise within the organization, which can be implemented by observing the performances of other colleagues and reflecting on what can be learned from their experience. This means that the awareness of teachers and healthcare professionals of different formats in which the development of new knowledge, skills and attitudes can be implemented is broadened.

In the case of teachers' answers in particular, it is important to take them into account in the context of the ongoing general education reform in Latvia, which emphasizes the continuous professional development of teachers through informal learning as a precondition to implement competency-based learning and make schools effective learning organizations. This means that elements of informal learning emphasized in the teachers' answers could confirm the desired rather than the actually used professional development formats.

The survey included a question on the purpose of professional development for teachers and healthcare professionals in order to find out how often in the answers of these groups there are indications of functional development - acquisition of new knowledge and skills for successful performance - and how often there are references to attitudinal development, which is related to the aspects of motivation, the acquisition of new attitudes and values. This question was asked based on the assumption mentioned in the scientific literature that the effectiveness of professional development improves if the learning outcomes include aspects of both functional and attitudinal development.

The data obtained in the study show that there are significant differences in the frequency with which references to functional and attitudinal development appear in the responses of teachers and healthcare professionals. In the answers of teachers, elements related to functional improvement are mentioned 48 times, while those related to the improvement of attitudes are only mentioned 2 times; the answers of healthcare professionals are similar -53 and 2 times. This leads to the conclusion that the previous learning experience of the surveyed teachers and healthcare professionals is more related to professional development goals, which include the acquisition of new knowledge and skills. However, insufficient attention has been paid to the development of new professional attitudes and values in order to broaden their understanding of various aspects of professional performance.

One healthcare respondent (female, 47) pointed out that professional development "is divided into two main parts - the formal one which is needed to be able to do a particular job, usually by collecting points, or (...) in a similar way. If you do not collect points, you cannot do the job. The 
second is informal [improvement], the one that improves your knowledge, skills, so that you can do work better, faster, more qualitatively, more creatively. Unfortunately, they are often unrelated."

Another healthcare respondent (male, 29) pointed out that the goal of professional development is "to improve and develop the existing knowledge and skills, as well as to acquire new knowledge and skills that give added value to me as a specialist in the field." These answers point to functional professional development, as they emphasize the need to improve existing knowledge and skills or to acquire new ones in order to effectively perform the duties set out in the job description.

Elements of attitudinal development can be illustrated by mentioning the answer of one of the healthcare respondents (female, 33) to the question with regard to how he understands the term "professional development": "Training in which knowledge and skills necessary for professional work are acquired. Also awareness of personal attitudes and purposeful work with a psychotherapist or other qualified professional." Another healthcare respondent (female, 46) stated: "By [this] concept I mean that professional development can go hand in hand with personal development that complements each other." Personal development, which includes the formation of attitudes and values as well as the review of existing beliefs, is an important aspect that enables healthcare professionals and teachers to deal with the challenges of a rapidly changing work environment and with an increasing emphasis on the satisfaction of clients.

The low proportion of elements of attitudinal development in the answers of the surveyed teachers and healthcare professionals is natural, considering that the respondents emphasized the importance of formal rather than informal learning experience for their professional growth. As part of formal professional development, it is easier to define a specific set of knowledge and skills that participants need to acquire in order to meet the requirements of a professional standard. In turn, the professional development of attitudes is implemented more through informal learning activities, where the formation of new attitudes, values and beliefs is a side effect of individual reflection and feedback received from colleagues and clients about the professional's performance.

A new, previously unplanned category of analysis was introduced during the coding of respondents' answers - "vagueness". The authors introduced this category in the face of a significant amount of content that could not be classified into the previously defined categories of analysis. "Vagueness" included responses whose content was too general and did not indicate the presence of the other defined study categories. Within the framework of the research, "vagueness" was found 40 times in the answers provided by teachers and 46 times in those by healthcare professionals. For example, 
the following response from teacher (female, 59) was found to be vague: "[Professional development] is a continuous growth activity to support students in the learning process so that their competence in the subject becomes the basis for their further life and work." Also, the answers that professional development is "professional growth" or "continuous development" were also found to be vague.

\section{Discussion}

The study conducted by the authors shows that the teachers and healthcare professionals who were involved in the present research confirmed a "narrow" understanding of the learning content to be acquired within the framework of professional development. Teachers and healthcare professionals reflecting on what professional development is emphasize the acquisition of new knowledge and skills but do not emphasize the need to develop one's personality by creating new or transforming already existing attitudes, values and beliefs, which is related to the sense of their professional role and responsibilities.

In the audience of surveyed teachers and healthcare professionals, when choosing professional development formats, formal learning activities dominate, such as attending courses, conferences and seminars, participation in workshops and masterclasses, etc., and they are less involved in informal learning activities in the workplace. As indicated above, this could be related to the traditions and habits of professional development in Latvia, which provide for a wider range of formal development formats, where participation can be confirmed by certificates, thus fulfilling the requirements of professional development specified in regulatory enactments.

Respondents' answers that include aspects related to informal learning are dominated by the independent analysis of scientific literature and acquaintance with the latest research results, while observing the professional activities of other colleagues in the organization is rarely mentioned. It is this aspect of informal learning that should be given additional attention by teachers and healthcare professionals, as learning from other colleagues' experiences, reflecting on experiences and providing feedback contribute to a similar understanding of professional performance standards in the organization and provide access to expertise and solutions.

In order to draw general conclusions about aspects of the professional development of teachers and healthcare professionals, further research needs to be conducted to find out the answers to other questions, for example, how the fact that teachers and healthcare professionals work in several jobs affects the choices made about their professional development. 
It should also be examined whether and to what extent the choice of professional development format of teachers and healthcare professionals is influenced by the length of their service and previous professional experience. There is a possibility that, over time, each professional group develops habits in terms of defining further learning goals and choosing the most appropriate professional development activities.

It is also important to research what the differences are between the chosen professional development formats for healthcare professionals and teachers and what the reasons are for these differences. This could be important due to the assumption that healthcare professionals, whose professional development is largely an individual learning activity, such as becoming acquainted with the latest medical research and scientific conclusions, are more involved in informal learning activities than teachers in whose professional field scientific innovations take place more slowly. Further research is also necessary to explore why teachers and healthcare professionals do not pay attention to informal learning in the workplace but, at the same time, use a wide range of formal learning opportunities, because both of these forms of development are necessary for teachers and healthcare professionals to reach professional standards.

\section{References}

Bergmark, U. (2020). Teachers' professional learning when building a research-based education: context-specific, collaborative and teacher-driven professional development. Professional Development in Education. https://doi.org/10.1080/19415257.2020.1827011

Billet, S. (2004). Workplace participatory practices: Conceptualizing workplaces as learning environments. Journal of Workplace Learning, 16(6), 312-324. https://doi.org/ $10.1108 / 13665620410550295$

Billett, S. (2011). Learning in the circumstances of work: The didactics of practice. Éducation et didactique, 5(5.2), 125-146. https://doi.org/10.4000/educationdidactique.1251

Cabinet of Ministers of the Republic of Latvia. (2012). Cabinet Regulation No. 943 "Procedure for Certification of Medical Practitioners". https://likumi.lv/ta/id/253782arstniecibas-personu-sertifikacijas-kartiba

Cabinet of Ministers of the Republic of Latvia. (2018). Cabinet Regulation No. 569 "Regulations on the Education and Professional Qualifications Necessary for Teachers and the Procedure for Improving the Professional Competence of Teachers". https://likumi. lv/ta/id/301572-noteikumi-par-pedagogiem-nepieciesamo-izglitibu-un-profesionalokvalifikaciju-un-pedagogu-profesionalas-kompetences-pilnveides

Cerasoli, C. P., Alliger, G. M., Donsbach, J. S., Mathieu, J. E., Tannenbaum, S. I., \& Orvis, K. A. (2018). Antecedents and outcomes of informal learning behaviors: A metaanalysis. Journal of Business and Psychology. 33(2), 203-230. https://doi.org/10.1007/ s10869-017-9492-y

Darling-Hammond, L., Hyler, M. E., Gardner, M. (2017). Effective teacher professional development. Palo Alto. CA: Learning Policy Institute. 
Desimone, L. M. (2009). Improving impact studies of teachers' professional development: toward better conceptualizations and measures. Educational Researcher, 38(3), 181-199. https://doi.org/10.3102/0013189X08331140

Eraut, M. (1994). Developing professional knowledge and competence. Routledge. https:// doi.org/10.4324/9780203486016

Eraut, M. (2004). Informal learning in the workplace. Studies on Continuing Education, 26(2), 173-247. https://doi.org/10.1080/158037042000225245

Evans, L. (2008). Professionalism, Professionality and the Development of Education Professionals. British Journal of Education Studies, 56(1), 20-38. https://doi.org/10.1111/ j.1467-8527.2007.00392.x

Evans, L. (2015). Professionalism and professional development: what these research fields look like today - and what tomorrow should bring. In Hillary Place Papers, $2^{\text {nd }}$ edition.

Given, L. M. (2008) Snowball Sampling. In Given, L. M. (ed.) The SAGE Encyclopedia of Qualitative Research Methods. Thousand Oaks: SAGE Publications, 816. https://dx.doi. org/10.4135/9781412963909

Guskey, R. T. (2002). Professional Development and Teacher Change. Teachers and Teaching: Theory and Practice, 8(3/4), 381-391. https://doi.org/10.1080/135406002100000512

Hargreaves, A., Fullan, M. (2012) Professional Capital: Transforming Teaching in Every School. New York, Routledge.

Jarvis, p. (2004). Adult education \& lifelong learning. Theory and practice, $3^{\text {rd }}$ edn. Routledge. https://doi.org/10.4324/9780203561560

Jeong, S., Han, S. J., Lee, J., Sunalai, S., \& Yoon, S. W. (2018). Integrative literature review on informal learning: Antecedents, conceptualizations, and future directions. Human Resource Development Review, 17(2), 128-152. https://doi.org/10.1177/ 1534484318772242

Jones, W. M., \& Dexter, S. (2014). How teachers learn: the roles of formal, informal and independent learning. Education Technology Research and Development, 62(3), 367-384. https://doi.org/10.1007/s11423-014-9337-6

Kumar, N., Ganguly, K. K. (2021). Impact of professionalism of workplace learning support team on learning outcome. Journal of Workplace Learning. Vol. 33, Issue 4, 287301. https://doi.org/10.1108/JWL-04-2020-0067

Louws, M. L., Meirink, J. A., van Veen, K., \& van Driel, J. H. (2017). Teachers' selfdirected learning and teaching experience: What, how, and why teachers want to learn. Teaching and Teacher Education, 66, 171-183. https://doi.org/10.1016/j.tate.2017.04.004

Louws, M. L., Meirink, J. A., van Veen, K., \& van Driel, J. H. (2017). Understanding teachers' professional learning goals from their current professional concerns. Teachers and Teaching, 24(1), 63-80. https://doi.org/10.1080/13540602.2017.1383237

Marsick, V. J., \& Watkins, K. (1990). Informal and incidental learning in the workplace. Routledge. https://doi.org/10.1177/074171369204200308

Marsick, V. J. \& Watkins, K. E. (2020) Informal and Incidental Learning in the time of COVID-19. Advancesin DevelopingHumanResources. 23(1), 88-96. https://doi.org/10.1177/ 1523422320973656

Marsick, V. J., Watkins, K. E., Callahan, W. M., \& Volpe M. (2008). Informal and Incidental Learning in the Workplace. In M. C. Smith \& N. DeFrates-Densch (Eds.), 
Handbook of research on adult learning and development (pp. 570-600). Routledge. https://doi.org/10.4324/9780203887882

Melnic, A. S., \& Botez, N. (2014). Formal, Non-Formal and Informal Interdependence in Education. Economy Transdisciplinary Cognition, 17(1), 113-118.

Ministry of Economics of the Republic of Latvia. (2020). Informative Report on Medium and Long-Term Forecasts of the Labor Market. https://www.em.gov.lv/files/ tautsaimniecibas_attistiba/dsp/EMzino_03062020-ar-pielikumiem.pdf

Mitchell, R. (2013). What is professional development, how does it occur in individuals, and how may it be used by educational leaders and managers for the purpose of school improvement? Professional Development in Education, 39(3), 387-400. https://doi.org/ 10.1080/19415257.2012.762721

Oliver, P. (2006). Snowball Sampling. In Jupp, V. (ed.) The SAGE Dictionary of Social Research Methods. London: SAGE Publications, 282. https://dx.doi.org/10.4135/ 9780857020116

Organization for Economic Co-operation and Development (OECD). (2019). The Future of Work. OECD Employment Outlook 2019. https://www.oecd.org/employment/EmploymentOutlook-2019-Highlight-EN.pdf

QSR International Pty Ltd. (2020) NVivo (released in March 2020). https://www. qsrinternational.com/nvivo-qualitative-data-analysis-software/home

Schreier, M. (2014). Qualitative Content Analysis. In Flick, U. (ed.) The SAGE Handbook of Qualitative Data Analysis. London: SAGE Publications, 170-183. https://dx.doi. org/10.4135/9781446282243.n12

Sjöberg, D., Holmgren, R. (2021). Informal Workplace Learning in Swedish Police Education - A Teacher Perspective. Vocations and Learning, 14, 265-284. https://dx.doi. org/10.1007/s12186-021-09267-3

Slotte, V., Tynjälä, P., \& Hytönen, T. (2004). How do HRD practitioners describe learning at work? Human Resource Development, 7(4), 481-499. https://doi.org/10.1080/ 1367886042000245978

Stevenson, A. (Ed.). (2010). Oxford dictionary of English. Oxford University Press. https://doi.org/10.1093/acref/9780199571123.001.0001

Susskind, R., \& Susskind, D. (2015). The future of professions: How technology will transform the work of human experts. Oxford University Press. https://doi.org/10.1093/ oso/9780198713395.001.0001

Troman, G. (1996). The rise of the new professionals? The restructuring of primary teachers' work and professionalism. British Journal of Sociology, 17(4), 473-487. https:// doi.org/10.1080/0142569960170404

Van Veelen, R., Sleegers, J. C. P., \& Endedijk, D. M. (2017). Professional Learning Among School Leaders in Secondary Education: The Impact of Personal and Work Context Factors. Educational Administration Quarterly, 53(3), 365-408. https://doi.org/ $10.1177 / 0013161 X 16689126$

Wardoyo, C., Herdiani, A. \& Sulikah, S. (2017). Teacher Professionalism: Analysis of Professionalism Phases. International Educational Studies. 10(4), 90-100. https://doi.org/ 10.5539/ies.v10n4p90

Wideen, M., Mayer-Smith, J., \& Moon, B. (1998). A critical analysis of the research on learning to teach: Making the case for an ecological perspective on inquiry. Review of Educational Research, 68(2), 130-178. https://doi.org/10.3102/00346543068002130 
World Bank. (2012). World Development Report 2013: Jobs. World Bank Group. https:// openknowledge.worldbank.org/handle/10986/11843

Zeggelaar, A., Vermeulen, M., Jochems, W. M. G. (2017). Exploring what works in professional development: An assessment of a prototype intervention and its accompanying design principles. https://doi.org/10.1080/19415257.2017.1402806 